1 Farmer perception of benefits, constraints and opportunities for silvoarable systems: preliminary insights from Bedfordshire, England

3 A.R. Graves ${ }^{1, *}$, P. J. Burgess ${ }^{1}$, F. Liagre ${ }^{2}$ and C. Dupraz ${ }^{3}$

$4 \quad{ }^{l}$ Cranfield University, Cranfield, Bedford MK43 OAL, UK

$5 \quad{ }^{2}$ Assemblée Permanente des Chambres d'Agriculture, 9 Avenue Georges V, 75008 Paris, France

$6 \quad{ }^{3}$ Institut National de la Recherche Agronomique, 2 Place Viala, 34060 Montpellier, France

7 *Corresponding author: a.r.graves@Cranfield.ac.uk

\title{
8 Abstract
}

9 Silvoarable agroforestry integrates the use of trees and arable crops on the same area of land, and such

10 systems can be supported by national governments under the European Union's (EU) Rural

11 Development Regulations (2014-2020). In order to improve understanding of farmers' perceptions of

12 such systems, detailed face-to-face interviews in 2003 were completed with fifteen farmers in

13 Bedfordshire, England. Most of these farmers thought that silvoarable systems would not be profitable on their farms and that benefits would tend to be environmental or social rather than economic. Most also thought that management and use of machinery would become more difficult. They felt that the tree component could potentially disrupt field operations and drainage, and expressed concern over the uncertain and long-term nature of timber revenue, and the effect of intercrop yield reductions on crop revenue. Even so, $20 \%$ of the farmers stated they would use silvoarable systems if convinced that they were more profitable than conventional arable farming. A further $20 \%$ said they would farm the intercrop area belonging to someone else, if the rent was reduced to compensate for crop yield reductions. These results suggest that for most arable farmers, an economic advantage over current practice needs to exist before silvoarable systems are likely to be adopted. However a minority might rent the crop component of a silvoarable system from another party, or implement a full system for perceived environmental or social benefits.

25 Keywords: Social survey, adoption, attitudes, risk, positive, negative

\section{Introduction}

27 Recent EU Rural Development Regulation 1305/2013 allows support to be provided for the establishment of agroforestry systems on agricultural land in the European Union. The European Commission (2004) has stated that such systems should be encouraged, because of their "high ecological and social value". Previous research supports this position (Palma et al., 2006). However, relatively little is known about how European farmers regard agroforestry systems. Most research regarding farmers' perceptions of agroforestry has been undertaken in tropical countries where it has sought to understand local practice (Barrance et al., 2003), opportunities for improvement (Fischler and

34 Wortmann, 1999; Dreschel and Rech, 1998), and the reasons for success or failure (Graves et al., 2004, 35 Franzel, 1999). 
Research on farmers' perceptions of agroforestry in temperate areas has focused on riparian strips

37 (Ducros and Watson, 2002), hedgerows (Morris et al., 2002), windbreaks (Matthews et al., 1993), or

38 silvopastoral systems (McAdam, et al., 1997). For example, Matthews et al. (1993) used a postal

39 questionnaire of landowners in Wellington County in Canada. The majority of those surveyed were

40 familiar with windbreaks, woodlots and plantations and interest in adopting such techniques was

41 relatively high; but fewer were aware of the practice of incorporating widely-spaced trees in cropped

42 fields or displayed an interest in doing this. Most felt that there would be little economic benefit in

43 adopting such systems because of the increased need for management. Although a minority stated they

44 would be interested in establishing agroforestry systems despite anticipated increases in labour and

45 overheads, widespread adoption would depend primarily on perceived economic benefits.

46 Lawrence and Hardesty (1992) also used a postal questionnaire in Washington State in the United

47 States of America, to survey three groups of land managers: employees of the Soil Conservation

48 Service, employees of the Washington State University Cooperative Extension Service, and a group

49 comprising university faculty members, private, state and federal land managers, and owners of natural

50 resource businesses. Of the $45 \%$ who responded to the survey, $94 \%$ were aware of agroforestry and of

51 these, 55\% had given advice on or implemented an agroforestry system themselves. The most

52 frequently cited potential application for agroforestry was in "government mandated" soil conservation

53 plans (100\%), range and pasture land (84\%), management of non-commercial forest land (84\%),

54 commercial forest plantations (83\%), and orchards (61\%). The perceived benefits were land use

55 diversity (25\%), enhanced productivity (18\%), aesthetics (13\%), and income diversity (13\%). The

56 identified constraints were lack of information (28\%), lack of technical assistance (18\%), establishment

57 costs (14\%), and the fact that it was not an established practice (14\%).

58 Workman et al. (2003) reported on a survey of landowners and extension professionals in Florida,

59 Alabama, and Georgia in the United States of America. Most farmers indicated that they used at least

60 one form of agroforestry practice, for example, riparian buffers or windbreaks. A small proportion, who

61 had established nut trees such as Pecan (Carya illinoinensis) and peach (Prunus persica) indicated they

62 had used the intercrop area for vegetables and cut flowers. Given a list of 16 potential benefits, farmers

63 in Florida and Alabama indicated that they felt the main advantages of agroforestry were aesthetic

64 value, shade, wildlife habitat, and soil conservation, increased land value and long-term investment

65 value. The same farmers identified the main constraints as competition between trees crops and

66 animals, lack of equipment, lack of information and markets, expense of management, lack of

67 familiarity with agroforestry, and lack of land and demonstrations.

68 This paper describes the results derived from a sample of farmers in Bedfordshire, England. The

69 principal objectives were to determine farmers' current awareness of silvoarable systems, to understand

70 their perception of the potential benefits and constraints, to understand what would motivate them to

71 use a silvoarable system, and finally to understand how they would then design and implement it. 
73 The interviews took place in Bedfordshire in Eastern England in 2003 (Figure 1) around the county 74 town of Bedford $\left(52^{\circ} 08^{\prime} \mathrm{N}, 0^{\circ} 27^{\prime} \mathrm{W} ; 95 \mathrm{~m}\right.$ above mean sea level). The mean annual temperature in 75 Bedfordshire (1971-2000) is about $9.6^{\circ} \mathrm{C}$, and the mean annual rainfall is about $580 \mathrm{~mm}$ (The 76 Meteorological Office, 2005). Bedfordshire covers 119,208 ha with a population of approximately 77381,600 . The agricultural area of 87,000 ha comprises $73 \%$ of the total area. In 2003, the agricultural 78 area was devoted principally to arable production comprising wheat (39\%), oilseed rape (10\%), barley

79 (7\%) and field beans for stock feed (6\%) (Defra, 2003). Set-aside (12\%) (land taken out of crop

80 production to reduce crop surpluses and provide environmental benefits), and grassland (16\%) were

81 also substantial. Woodlands comprised only $2 \%$ of the agricultural area and $7 \%$ of the total area (i.e.

82 including non-farm woodlands). In June 2003, 535 out of a total of 1,414 farm holdings were involved 83 in cereal production (Defra, 2003). The pre-dominance of arable agriculture with relative low levels of 84 tree cover means that there are potential opportunities for silvoarable agroforestry.

85 An open and closed format questionnaire (Neuman, 2000), also described by Liagre et al. (2005), was used as a schedule (Wilson, 1996) for individual face-to-face interviews with farmers, farm managers and land owners. Quantitative and qualitative data collected during the interviews were entered directly onto a laptop computer. The interviews were semi-structured since questions were not always asked in the order on the questionnaire because farmers often volunteered information that answered un-asked questions. This flexibility helped to maintain the flow of the interview. The questionnaire was divided into several sections. The first two sections aimed to determine background information on the farmer and farm business, their understanding of silvoarable systems, and their attitude to trees. The third section included a demonstration of silvoarable systems using images on the computer so that farmers were aware of the general nature of silvoarable agroforestry. The fourth section aimed (i) to establish if the images corresponded to farmers' preconceptions of silvoarable systems, (ii) to determine the perceived positive and negative aspects of the silvoarable systems shown, and (iii) to determine what might motivate them to implement silvoarable agroforestry. The final three sections aimed to determine how farmers would design a silvoarable system, how they would implement it, and to determine if, after the interview, they would be interested in using silvoarable agroforestry themselves.

100 A sampling frame (Schofield, 1996) of commercially active arable farmers in Bedfordshire was used to 101 select 15 farmers for interview between January and March 2004. Bedfordshire was divided into four 102 areas (north-west, north-east, south-west and south-east) to ensure even geographical coverage of the 103 interviewees. Farmers' positive and negative perceptions of silvoarable systems and the reasons given 104 for possible use of a silvoarable system were first examined in terms of the frequency of response. They 105 were also characterised using a weighted index (Neuman, 2000), here called the "aggregate weighted 106 rank" $\left(R_{\mathrm{a}}\right)$. This gave greater weight to a response if the farmer gave it a higher rank and the value of $R_{\mathrm{a}}$ was calculated by aggregating the ranked importance of each perception (Equation 1), so that: 
$108 \quad R_{a}=\sum_{s=1}^{s=n} R_{i}^{-1} \quad$ Equation 1

109 Where $R_{i}$ is the integer rank given to a perception by the farmer during interview, and $n$ is the number

110 of farmers in the sample $(s)$.

111 The responses to open format questions and comments volunteered by the farmers during the

112 interviews, which had been entered on a computer, were disaggregated and coded (Strauss and Corbin,

113 1998) according to thematic content and collected in tabular summaries. They were then used to

114 substantiate responses to closed format questions, i.e. triangulation of method (Neuman, 2000),

115 introduce new themes and explanations in the analysis, and illustrate the discussion with direct quotes

116 from the farmers.

\section{Results}

\section{Farmer sample}

119 The sample consisted entirely of male farmers, ranging in age from 36 to 63 years old. The mean age

120 was 45, with most between 45 and 49 years of age. Eight farmers had potential successors, most of

121 whom were younger than 20 years old. Twelve owned at least part of the farm business, two were

122 tenants, and one was a non-owner manager. Decisions made regarding the farm were mostly made by

123 the individual farmer. The area cropped by the sample farmers ranged from 42 to 2000 ha, with a

124 median area of 200 ha; the mean value of 410 ha was skewed by two large farms. Eleven farmers

125 owned and rented land, two only rented land, and two were farm-business managers who neither owned

126 nor rented land. The mean owned area was 155 ha (range: 42 to 315 ha) and the mean rented area was

12766 ha (range 12 to 202 ha). Ten farms specialised in crop production whilst five farms included

128 livestock enterprises. Most of the farms employed fewer than two workers, but the two largest

129 employed 13 and 19 people.

130 Attitude to trees and knowledge of agroforestry

131 All 15 farmers indicated that they "liked" trees and each farm had hedgerows (range: from less than 5

$132 \mathrm{~km}$ to more than $20 \mathrm{~km}$ ). On most farms, trees and crops were separated; nine had no trees at all in

133 arable areas, three had 1 to 19 trees, and three had more than 30 trees. Most were mature trees planted

134 by previous owners; only one farmer had recently planted trees in the cropped area of the farm as part

135 of a demonstration project (Burgess et al. 1999). On eleven farms, individual trees had been removed to

136 allow machine access (4 cases), improve crop productivity (4 cases), and to deal with tree disease (4

137 cases). Of the five farmers who had not removed trees, three stated this was for landscape benefit, and

138 one farmer specified production benefits because the trees helped to dry "heavy" soil. Eight out of the

13915 farmers said they had already heard of agroforestry either through technical papers (2 cases),

140 newspapers ( 1 case), personal experience ( 2 cases) or other unspecified sources ( 3 cases). Five said they 
141 had seen agroforestry and three that they knew someone using agroforestry. However, the farmers had 142 different definitions of agroforestry; two said that it was an association of trees and crops, four that it 143 was tree-planting on arable land, and one that it could be both of these.

\section{Positive and negative perceptions of silvoarable systems}

145 Most farmers thought that benefits of silvoarable agroforestry would be social and environmental,

146 rather than economic. The most frequently mentioned benefits were for farmer image, biodiversity,

147 landscape, farm diversification, soil conservation, and timber production (Figure 2a). Two farmers

148 mentioned intercrop productivity as a benefit, since silvoarable systems allowed farmers to maintain

149 crop production whilst creating a tree-based environment, whereas this was not possible with forestry.

150 The aggregate weighted rank showed that farmer image was seen as the most important benefit $\left(R_{a}=\right.$ 151 3.5), as well as most frequently mentioned benefit (Figure 2a). Soil conservation was given almost as 152 much importance $\left(R_{a}=3.4\right)$ as farmer image. Other benefits given high importance included landscape

153 benefits, production of timber, high quality timber production, farm diversification, biodiversity, and 154 general environment.

155 Negative perceptions of silvoarable agroforestry revolved around management, feasibility and

156 production issues (Figure $2 \mathrm{~b}$ ). The most frequently mentioned negative perceptions were linked to use 157 of farm machinery, complexity of work, general project feasibility and the effect of the trees on crop 158 productivity. The greatest aggregate weighted rank $\left(R_{a}=5.5\right)$ was for mechanisation (Figure $2 \mathrm{~b}$ ) 159 suggesting that farmers anticipated difficulties with machinery use in silvoarable systems. The value 160 this achieved in terms of aggregated weighted rank was greater than any of the positive perceptions. 161 Project feasibility $\left(R_{a}=3.9\right)$, complexity of work $\left(R_{a}=3.9\right)$, and intercrop productivity $\left(R_{a}=3.4\right)$ were 162 also given high aggregate weighted ranks in terms of negative perception.

\section{Reasons for using a silvoarable system}

164 When asked to state the reasons, in an imaginary situation, for using silvoarable systems on their farm, 165 the most frequently stated reasons were the general environment, biodiversity, timber production, profit, 166 and the benefit from subsidies (Figure 3). The reason with the highest aggregate weighted rank was 167 profit $\left(R_{a}=3.0\right)$. The frequencies and aggregate weighted ranks were generally lower than those for 168 negative perceptions of silvoarable systems, indicating that farmers placed greater emphasis on negative 169 aspects than anticipated reasons for implementing silvoarable agroforestry.

\section{$170 \quad$ Implementation of a silvoarable system}

171 Most farmers said they would use poor land (7 cases) and avoid planting along the contours (11 cases).

172 Approximately half envisaged a secondary product from the trees in addition to timber (6 cases) and 173 most stated this would be fruit (4 cases); firewood, grass, and bio-fuels were also mentioned. The 174 greatest difficulties with farm machinery dimensions were related to spray widths ( 9 cases) and the 175 height of the combine harvesters ( 5 cases). Farmers identified oak, poplar, and wild cherry as the 
176 preferred species. The other tree species mentioned more than once were ash, walnut, and willow. Most

177 farmers were keen to maintain their current choice of crops and the preference was for autumn- rather

178 than spring-planted crops. The crops most likely to be used were wheat, oilseed, barley, field beans and 179 grass.

180 Farmers were divided evenly on whether or not irrigation would be possible in silvoarable systems.

181 Eight farmers said they would avoid some agrochemicals because of the trees, compared to six who said

182 they would not alter their agrochemical use. Decreasing intercrop width over time was not considered to

183 be viable by most farmers. Three explained this because of machinery restrictions and one because of a

184 desire to maximise crop return. By contrast two farmers stated that they would reduce the intercrop

185 width, by blocking lines in the seed drill, to save on management costs or to minimise obstruction and

186 damage to machinery as the trees grew. Most farmers said they would turn the intercropped area to

187 pasture when an arable crop was no longer profitable.

188 Twelve of the fifteen farmers said they would undertake the tree operations themselves. Farmers said

189 they would manage the tree row at planting by leaving it bare (5 cases), seeding it (4 cases), using a

190 plastic mulch (3 cases), natural regeneration ( 2 cases), and using herbicides ( 1 case). The most

191 commonly stated maintenance practice for the tree row was herbicide use (8 cases), rather than mowing

192 (3 cases), or integrated herbicide and mowing strategy (4 cases).

193 Most farmers said they would plant less than 15 ha of land to silvoarable agroforestry. This was

194 equivalent to a mean of $13 \%$ of the land of each farm (Table 1). Most farmers ( 6 cases) said they would

195 plant one contiguous area. Three said they would use a tree row distance of less than $20 \mathrm{~m}$, but most (9

196 cases) said they would use a tree row distance of between 20 and $34 \mathrm{~m}$. Five selected an in-row distance

197 of less than $4 \mathrm{~m}$ and four said they would use an in-row tree distance of 5-9 $\mathrm{m}$. These dimensions result

198 in a tree density of less than 100 trees $\mathrm{ha}^{-1}$ for seven farmers, and 100-200 trees ha ${ }^{-1}$ for five farmers.

199 The mean planting density was 102 trees ha $^{-1}$ (range 17 to 333 trees ha ${ }^{-1}$ ). Most farmers $(11$ cases) said

200 they would use an intercropping width of less than $30 \mathrm{~m}$ (mean $25 \mathrm{~m}$, range $12-72 \mathrm{~m}$ ). The majority (6

201 cases) preferred a headland width of 15-19 m, but four said they would use headlands of more than 35

$202 \mathrm{~m}$ (mean $27 \mathrm{~m}$, range: 3 to $60 \mathrm{~m}$ ). Finally, most farmers (10 cases) said that the minimum width of the

203 plot would be between 50 and $150 \mathrm{~m}$ (mean $122 \mathrm{~m}$, range 40 to $316 \mathrm{~m}$ ) and that the minimum practical

204 length for a plot of land would be between 100 and $250 \mathrm{~m}$ (mean $198 \mathrm{~m}$, range 100 to $450 \mathrm{~m}$ ). The tree-

205 row distance, intercrop widths, and headland widths were generally related to machine requirement

206 (Table 2). However, the in-row tree distances were based on tree needs and the minimum plot width and

207 length were justified for reasons of "plot area".

208 When the farmers were asked how they would undertake the project, they were divided on whether they

209 would opt for a collective or individual project, but the majority were ready to share machine and

210 worker costs. Those wishing to work in a joint project suggested other farmers (7 cases), family (3

211 cases), enterprises and local group (1 case each). Most said they would make planting decisions alone, 
212 although some said they would discuss it with family. Six farmers said that under the right

213 circumstances they would consider using the intercrop area on another farm if it was proposed to them;

214 five said they would not and four were undecided. Seven opposed the idea of a landlord establishing a

215 silvoarable project on the land they rented, but four said they would agree under the right

216 circumstances, and five didn't know. Of the seven farmers who responded regarding tree establishment

217 costs, four said they would not be willing to pay more than $50 \%$ of the establishment costs. All but one

218 farmer said they would need technical advice on tree and crop husbandry in a silvoarable system.

219 Finally, when asked to score an opinion of silvoarable systems on a scale of zero (low) to ten (high)

220 most farmers gave low scores. Ten said they would not consider establishing a silvoarable system

221 themselves, but three said they might consider it under the right conditions. Most stated that age was not

222 a deciding factor in this decision; three stated that it was with one farmer saying he "would like to be

223 alive when the trees are harvested".

\section{Discussion}

\section{Field management constraints}

226 Many farmers felt there would be difficulties in managing the system. One stated, "Why change the 227 separation of crops and trees which is practical?" Another said that, "fields are the factory floor of the 228 farm and trees in fields are obstacles".

229 Machinery: Farm machinery is fundamental to conventional arable farming and successful silvoarable 230 systems need to be designed accordingly. There was a consensus that intercrop widths would have to be 231 a multiple of common widths of sprayers, combine harvesters and seed drills to avoid overlapping. One

232 farmer was concerned about inflexibility, stating that once the intercrop width was set, increasing

233 sprayer width in the future would be impossible. One farmer noted that even after tree harvest, the 234 stumps or the hollows left after their removal could be problematic for machinery. There was also a 235 general consensus that operating machines in silvoarable systems would lead to increased difficulties 236 and costs and reduced speed of operations. Several stated that combine harvesters could be damaged by 237 tree branches, leading to expensive repairs. Most stated they would not plant along the contour, because 238 field shape could make this impractical and because moving across slopes was more difficult in farm 239 machines. One farmer stated that tree rows would make it impossible to work the soil in different 240 directions. This would result in soil compaction along vehicle tracks running up and down the slope and 241 increased soil erosion. Interestingly, one farmer who had established a silvoarable plot on his own farm 242 in the mid 1990s did not mention mechanisation problems or raise issues concerning complexity of 243 work during the interview.

244 Crop and tree growth: farmers were concerned about growth of trees and crops in mixed systems. Most 245 felt that the trees would reduce crop yields because of competition for light, and the possibility that 246 arable production might be curtailed before the end of the tree rotation was untenable to some. They 
247 often said that the system's spatial-design should prevent this, and some suggested harvesting the trees

248 prematurely, before crop yields were significantly reduced. Some farmers also considered that arable

249 operations would reduce tree growth. For example, ploughing might damage trees roots, and herbicides

250 used on the crop could damage the trees. Several farmers therefore stated that they would avoid using

251 non-selective herbicides and several mentioned avoiding the use of insecticides that might kill

252 beneficial insects in the tree strip.

\section{Socio-economic and environmental constraints}

254 Although some farmers felt that silvoarable agroforestry was an attractive and interesting idea, the majority thought it was inappropriate. One said that it was "not the right idea for this part of the

256 country" and another that it had "limited application in the eastern part of England". Particular concerns 257 related to land value, landscape, biodiversity and flexibility.

258 Land value: One farmer said "putting trees on arable land could render the land almost valueless"

259 because potential buyers would see the trees as a hindrance and would want them cleared. Another said

260 that if the land was bound in a long-term commitment after receiving grants, it would make sale to

261 developers and other landowners difficult.

262 Landscape and biodiversity: Two farmers stated that single rows of trees in the landscape were "ugly"

263 and would not consider using silvoarable systems because of this. Although the farmers stated that they

264 liked trees, and many had planted them on their farms, they felt that they belonged to woodlands or

265 hedgerows. Several commented that silvoarable systems appeared to support less biodiversity than

266 conventional woodlands with dense tree cover, and that herbicide operations would create sterile tree

267 strips.

268 Flexibility: Many farmers felt that silvoarable agroforestry was inflexible and were worried about long-

269 term limitations if "circumstances changed". Several farmers felt that there were too many uncertainties

270 regarding the system. One stated that he would prefer others to be "guinea-pigs" as he was not "a leader

271 in new ideas". Another was concerned that policy could change and that support for the system could be

272 withdrawn, once he was committed. For example, trees could have preservation orders put on them, as

273 the public might start to feel the trees were important landscape features. He cited the case of a local

274 farmer who had difficulties felling trees that had been planted to produce timber. Another stated that

275 deliberate vandalism could be a long-term problem. Two farmers suggested that the only planting of

276 trees on arable land farmers would contemplate related to making the field a more regular shape so that

277 it could be farmed efficiently with machinery. Otherwise, planting of trees was restricted to

278 unproductive or low quality land. These issues were summed up by one farmer who said, "You put trees

279 and woodland where you can't grow a crop, or for hunting or the environment or to make a field

280 square". 
Profitability: Most farmers perceived that silvoarable systems would be less profitable than current arable cropping. They were concerned with a potentially poor market for timber and increased costs of crop production. One farmer stated that silvoarable systems would make marketing timber difficult with "small amounts (of timber) in small places". Another stated that in England, there was no longer any market for low quality wood. Another stated "timber the world over is cut for less than the cost of production". He concluded that timber trees can only make money "if they are inherited or have grown naturally". Concern about increased crop production costs was attributed to the trees reducing light availability in the intercrop area. One farmer indicated that shading by trees would also cause differential ripening which would make harvesting problematic.

290 Several stated that damage to machinery caused by collisions between, for example, combine harvesters 291 and the trees could be expensive. Several farmers considered that the area at the base of trees would

292 lead to additional costs, partly because of weed and pest invasion. One farmer said that root

293 encroachment into drains would impede field drainage which would be expensive to remedy.

294 Opportunities for silvoarable systems

295 Although farmers were open to the benefits of using trees on farms and many stated that they had a role 296 to play, few felt that in England, this would be in an integrated tree-crop system on arable land.

297 However, several mentioned that they could see advantages of such systems in a Mediterranean context 298 where annual crops were obtained from the trees. Nevertheless, seven farmers (46\%) were willing to 299 use a silvoarable system in some form. Three farmers (20\%) (Table 3: Q.2) were willing to use it on 300 their own land if convinced it was more profitable than their current enterprise, and a further four 301 farmers (26\%) (Table 1: Q.1) were willing to use an intercrop area rented from another party. A subset 302 of these two groups (Table 3: Q.3) was also willing to accept the implementation of silvoarable 303 agroforestry on land they rented from a landlord. However, this willingness came with the proviso that 304 such use should be profitable, either due to the inherent financial performance of the system, the 305 availability of grants, or because of satisfactory adjustments to rent.

306 Most farmers stated that they would establish a silvoarable system on their worst land because they 307 would not want to reduce the income from their best land. One farmer felt that the system would be 308 most appropriate for an organic farm, where spray damage was not an issue and suggested an entire 309 chronology for the intercrop. Cereals could be grown for the first five years, then the intercrop area used 310 for grass production for silage, because "greenness" doesn't matter in silage production. Because grass 311 doesn't need spraying, the tree component would not be damaged. Most farmers however said they 312 would continue to use cereals as this was what the farm business was already equipped to do. Several 313 stated that they would stop using oilseed rape owing to bird problems.

314 Many had suggestions regarding the tree component. Several thought that integrating trees with farming 315 was most appropriate where there were livestock and where it was possible to obtain an annual harvest 
316 from the trees. Christmas trees and hops were suggested as options. Two suggested that trees should be 317 selected on the basis of canopy architecture to minimise their impact on crop yields. One felt that rather 318 than planting single rows of trees, several rows of mixed species could be planted with wider

319 intercropping areas. This would preserve the per hectare density of the trees, be more suited to modern

320 farm machinery, and enhance biodiversity, because the tree habitat would be superior. There were two

321 potentially divergent objectives regarding tree species, either they should provide rapid returns from

322 timber production or be planted for landscape value and long-term quality timber production. One

323 farmer suggested that returns from the tree component could be reduced to just several years by

324 growing ornamental standards for use by town developers. This would provide an earlier return on the

325 money invested and reduce shading of the crop, because trees would be harvested before the canopy

326 became dominant.

\section{Opportunities for adoption}

328 Pannel (1999) reported that four conditions were necessary for adoption of new systems. Farmers must

329 (i) be aware of the system, and they must consider that, (ii) it can be trialled, (iii) that it is worth

330 trialling, and (iv) that it meets important components of "self-interest" such as profit. The results

331 suggest that these conditions are some way from being fulfilled in Bedfordshire. Only a few of the

332 farmers are aware of silvoarable agroforestry. In addition, the long-term nature of silvoarable

333 agroforestry makes it difficult for an individual farmer to trial, because of the long-term commitment of

334 land, labour, and capital. Finally, the results demonstrate that most farmers do not believe that

335 silvoarable agroforestry can increase profitability and the last condition suggested by Pannel (1999) is

336 therefore also lacking. The sampled farmers considered that the major benefits of silvoarable

337 agroforestry would be environmental and social rather than financial. Although wider factors of "self-

338 interest" such as stewardship, or farmer image might motivate a small number of farmers to use

339 silvoarable systems, if required on a wider scale, it appears that silvoarable systems will need to be

340 encouraged through agri-environment schemes such as proposed by the European Council in their Rural

341 Development Regulations.

\section{Conclusions}

343 Previous research has shown that silvoarable agroforestry can provide greater environmental and social

344 benefits than arable cropping (Palma et al. 2006). Such benefits are sought by the European Union and

345 these can be provided whilst maintaining crop production and diversifying into timber production.

346 Moreover, appropriate application of agroforestry provide the EU with a potential approach to helping

347 the EU achieve more resource efficient, sustainable, low emission food and fibre production as outlined

348 in the Europe 2020 strategy (EC 2011) whilst providing an improved quality and diversity of rural life

349 (EC 2005), reducing deforestation (EC 1999), and reducing biodiversity loss (EC 2011). However, the 
interviews reported here suggest that use of silvoarable agroforestry is unlikely to increase significantly amongst arable farmers in Bedfordshire and beyond, since the appropriate conditions for adoption, as described by Pannel (1999), are lacking. A coherent effort of research, promotion, and support will be

353 required for silvoarable agroforestry to be seen as a viable option by farmers. Future research needs to 354 quantify the public as well as private benefits of silvoarable agroforestry, whilst successfully tackling the issues that farmers see as important. This study helps to identify such key areas for future research. Specifically, there is a need to revisit the on-farm economics of agroforestry demonstration sites such as those established in Bedfordshire in the late 1990s (Burgess et al., 1999). From this survey, it appears that particular concerns relate to understanding the implications for mechanised arable operations, longterm timber values, and the effect of trees on land value. Suggestions made by farmers for the tree component could also be investigated. For example, growing ash, cherry, or short rotation willow coppice as short-term trees, and hops or fruit trees to provide an annual income could be examined.

362 Further options include examining the combined use of short and long-term trees in the tree row and use of several tree rows instead of single trees rows. It would also be useful to determine if there are regional variations in perceptions of silvoarable agroforestry in England and Europe, and if certain

365 types of farmer (e.g. organic farmers), or farmers in areas with certain environmental problems (e.g. treeless areas with high wind erosion) are more receptive to using silvoarable agroforestry. Such areas and groups of farmers could potentially become focal points for promotion of silvoarable agroforestry.

368 A major new EU sponsored agroforestry project, the AGFORWARD project 369 (https://www.agforward.eu/index.php/en/) is examining some of these issues and readers can refer to 370 this to find more on the latest research on different types of European agroforestry systems.

\section{Acknowledgement}

372 This research was carried out as part of the SAFE (Silvoarable Agroforestry for Europe) collaborative 373 research project, funded by the EU under its Quality of Life programme (QLF5-CT-2001-00560). We 374 also thank the farmers in Bedfordshire who agreed to be interviewed.

\section{References}

376 Barrance, A.J., Flores, L., Padilla, E., Gordon, J. E. and Schreckenberg, K. (2003). Trees and farming 377 practices in the dry zone of southern Honduras I: campesino tree husbandry practices. Agroforestry $378 \quad$ Systems 59 (2): 97-106. 
Burgess, P.J., Brierley, E.D.R. \& Goodall, G.R. (1999). The financial costs of farm woodland

Commission of the European Union (2004). Proposal for a Council Regulation on support for rural establishment at four sites in Bedfordshire, England. In: Burgess, P.J., Brierley, E.D.R., Morris, J. \&

Department for Environment Food and Rural Affairs (2003). Agricultural and Horticultural Census: June 2003 for Bedfordshire County Council. York, England.

Dreschel, P. and Rech, B., (1998). Composted shrub-prunings and other organic manures for smallholder farming systems in southern Rwanda. Agroforestry Systems 39(1): 1-12.

European Commission (2004). Proposal for a Council Regulation on support for rural development by

European Commission (1999). Council resolution on a forestry strategy for the European Union http://eur-lex.europa.eu/LexUriServ/LexUriServ.do?uri=OJ:C:1999:056:0001:0004:EN:PDF

European Commission (2005). Council Regulation (EC) No 1698/2005 of 20 September 2005 on support for rural development by the Europan Agricultural Fund for Rural Development (EAFRD). Official Journal of the European Union L 277/1. http://eur-lex.europa.eu/LexUriServ/site/en/oj/ 2005/1_277/1_27720051021en00010040.pdf

European Commission (2011). A Resource-Efficient Europe - Flagship initiative under the Europe 2020 Strategy. $\operatorname{COM(2011)~21.~http://ec.europa.eu/resource-efficient-Europe/pdf/~}$ resource efficient europe en.pdf

Fischler, M. and Wortmann, C.S. (1999). Green manures for maize-bean systems in eastern Uganda: agronomic performance and farmers' perceptions. Agroforestry Systems 47 (1/3): 123-138.

Franzel, S. (1999). Socio-economic factors affecting the adoption potential of improved tree fallows in

408 Graves, A.R., Matthews, R.B. and Waldie, K. (2004). Low external input technologies for livelihood 409 improvement in subsistence agriculture. Advances in Agronomy 82: 473-555.

410 Lawrence, J.H. and Hardesty, L.H. (1992). Mapping the territory: agroforestry awareness among 411 Washington State land managers. Agroforestry Systems 19(1): 27-36. 
413 Mantzanas, K., Dupraz, C. (2005). Deliverable 2.3. Survey of farmers' reaction to modern silvoarable systems in Europe: Will European farmers adopt silvoarable agroforestry technology in the near future? Report prepared for the SAFE project. Paris, France: APCA 30 April 2005, 104 pp. (Accessed May 2005). http://montpellier.inra.fr/safe/.

Matthews, S., Pease, S.M., Gordon, A.M. and Williams, P.A. (1993). Landowner perceptions and the adoption of agroforestry practices in southern Ontario, Canada. Agroforestry Systems 21(1): 11-25.

McAdam, J., Gazeau, S. and Pont, F. (1997). An assessment of farmer attitudes to agroforestry on sheep and cereal farms in Northern Ireland. Agroforestry Forum 8(3): $5-8$.

Morris, R.M., Oreszczyn, S.M., Sloate, C. and Lane, A.B. (2002). Farmers' attitudes, perceptions and the management of field boundary vegetation on farmland. In: Frame, J. (ed), Conservation pays? Reconciling environmental benefits with profitable grassland systems. Proceedings of the joint British Grassland Society/British Ecological Society Conference, University of Lancaster, 15-17 April, 2002.

Neuman, W.L. (2000). Social Research Methods: Qualitative and Quantitative approaches, $4^{\text {th }}$ Edition. Allyn and Bacon, Massachusetts, United States of America.

Palma J., Graves A.R., Bunce R., Burgess P., de Filippi R., Keesman K., van Keulen H., Mayus M., Reisner Y., Liagre F., Moreno G., Herzog F (2006). Modelling environmental benefits of silvoarable agroforestry in Europe. Agriculture, Ecosystems and Environment. In Press.

Pannel, D. J. (1999). Social and economic challenges in the development of complex farming systems. Agroforestry Systems 45(1/3): 393-409.

Schofield, W. (1996). Survey Sampling. In: Sapsford, R. and Jupp, V. (eds.), Data Collection and Analysis. SAGE Publications Ltd, London, England.

Strauss, A. and Corbin, J. (1998). Basics of Qualitative Research: Techniques and Procedures for Developing Grounded Theory. $2^{\text {nd }}$ edition. SAGE Publications Ltd, London, England.

The Meteorological Office (2005). Database of United Kingdom climate and weather statistics: Thirty year averages between 1971-2000. (Accessed 5 May 2005). http://www.metoffice.com/.

Wilson, M. (1996). In: Sapsford, R. and Jupp, V. (eds.), Data Collection and Analysis. SAGE

Workman, S.W., Bannister, M.E. and Nair, P.K.R. (2003). Agroforestry potential in the south-eastern 442 United States: perceptions of landowners and extension professionals. Agroforestry Systems 59(1) $443 \quad 73-83$. 
Table 1 Summary of plot dimensions that farmers would use in a silvoarable system $(n=13-15)$.

\begin{tabular}{llllll}
\hline \multicolumn{1}{c}{} & & Median & Mean & Minimum & Maximum \\
\hline Area of plots (ha) & & 10 & 20 & 2 & 100 \\
Proportion of farm area (\%) & & 6 & 13 & 0.1 & 100 \\
Number of plots (n) & 2 & 3 & 1 & 10 \\
Distance between tree lines & (m) & 26 & 26 & 15 & 50 \\
Distance between trees on line & $(\mathrm{m})$ & 5 & 7 & 2 & 20 \\
Tree density (trees ha ${ }^{-1}$ ) & 71 & 102 & 17 & 333 \\
Intercropping width in first year (m) & 22 & 25 & 12 & 72 \\
Intercropping width in last year (m) & 22 & 25 & 9 & 72 \\
Width of headland (m) & 20 & 27 & 3 & 60 \\
Minimum width of plot (m) & & 100 & 122 & 40 & 316 \\
Minimum length of plot & (m) & 200 & 199 & 100 & 450 \\
\hline
\end{tabular}

Table 2 The number of times that eight possible criteria were used by farmers to justify the plot dimensions shown in Table $1(n=14-15)$.

\section{Criteria used to justify plot dimensions}

\begin{tabular}{|c|c|c|c|c|c|c|c|c|}
\hline & $\begin{array}{l}\text { Machine } \\
\text { priority }\end{array}$ & $\begin{array}{l}\text { Tree } \\
\text { priority }\end{array}$ & $\begin{array}{l}\text { Plot } \\
\text { area }\end{array}$ & $\begin{array}{l}\text { Crop } \\
\text { priority }\end{array}$ & $\begin{array}{l}\text { Field } \\
\text { surface }\end{array}$ & $\begin{array}{l}\text { Association } \\
\text { optimisation }\end{array}$ & Other & Rules \\
\hline \multicolumn{9}{|l|}{ Plot dimensions } \\
\hline Tree row distance & 12 & & & 1 & & & 1 & 1 \\
\hline In-row tree distance & 3 & 9 & & 3 & 1 & & & 1 \\
\hline $\begin{array}{l}\text { First year intercrop } \\
\text { width }\end{array}$ & 13 & 3 & & 2 & & & & \\
\hline $\begin{array}{l}\text { Last year intercrop } \\
\text { width }\end{array}$ & 10 & 1 & & 3 & & 1 & & \\
\hline Headland width & 12 & 1 & & & & 1 & & \\
\hline Plot minimum width & 5 & & 5 & & 2 & 1 & 2 & \\
\hline $\begin{array}{l}\text { Plot maximum } \\
\text { width }\end{array}$ & 6 & & 5 & & 2 & 1 & 1 & \\
\hline Total & 61 & 14 & 10 & 9 & 5 & 4 & 4 & 2 \\
\hline
\end{tabular}

Table 3 The responses of the sample of farmers $(n=15)$ to questions concerning the use of silvoarable systems in various hypothetical situations.

\begin{tabular}{|c|c|c|c|c|c|c|c|c|c|c|c|c|c|c|c|}
\hline \multicolumn{16}{|c|}{ Farmer (n) } \\
\hline & 1 & 2 & 3 & 4 & 5 & 6 & 7 & 8 & 9 & 10 & 11 & 12 & 13 & 14 & 15 \\
\hline $\begin{array}{l}\text { 1. If a neighbour proposed an } \\
\text { intercrop area for you to } \\
\text { use, would you accept? }\end{array}$ & $?$ & $X$ & $X$ & $\sqrt{ }$ & $?$ & $X$ & $X$ & $\sqrt{ }$ & $X$ & $\sqrt{ }$ & $\sqrt{ }$ & $?$ & $?$ & $\sqrt{ }$ & $\sqrt{ }$ \\
\hline $\begin{array}{l}\text { 2. Would you implement } \\
\text { silvoarable agroforestry on } \\
\text { your own land? }\end{array}$ & $X$ & $X$ & $X$ & $X$ & $\sqrt{ }$ & $?$ & $X$ & $\sqrt{ }$ & $X$ & $X$ & $?$ & $X$ & $X$ & $X$ & $\sqrt{ }$ \\
\hline $\begin{array}{l}\text { 3. If your landlord proposed } \\
\text { to implement silvoarable } \\
\text { agroforestry on land you } \\
\text { rent, would you agree? }\end{array}$ & $?$ & $X$ & $X$ & $X$ & $\sqrt{ }$ & $X$ & $X$ & $?$ & $X$ & $\sqrt{ }$ & $\sqrt{ }$ & $?$ & $?$ & $X$ & $\sqrt{ }$ \\
\hline
\end{tabular}


Figure 1 The location of Bedfordshire in England.

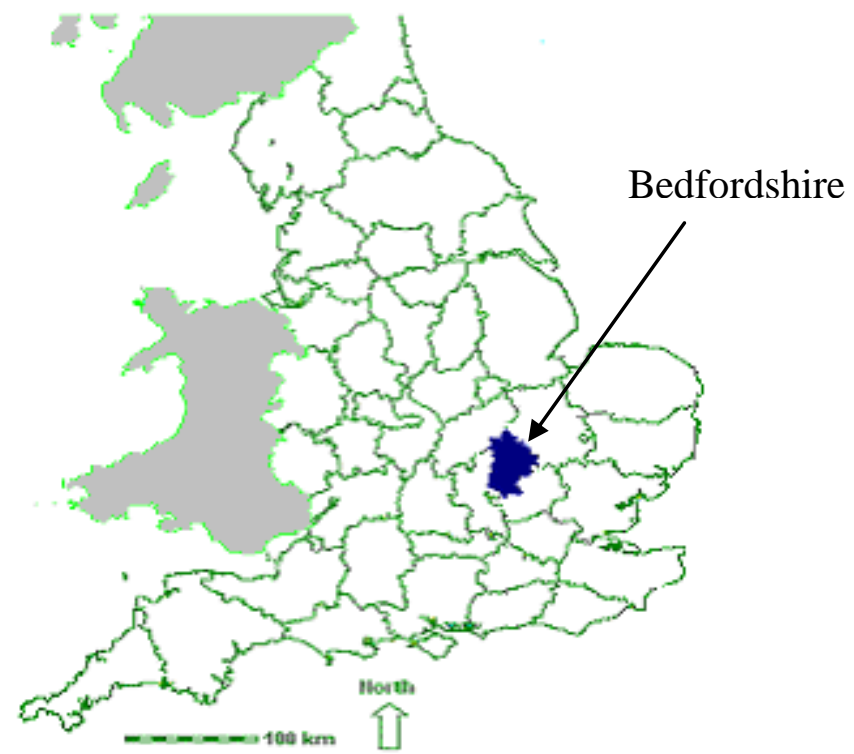


Figure 2 The aggregate weighted rank $\left(R_{a}\right)$ and frequency of response for (a) positive and (b) negative perceptions of silvoarable systems given by the sample of farmers in Bedfordshire $(n=15)$.

a) Positive perceptions

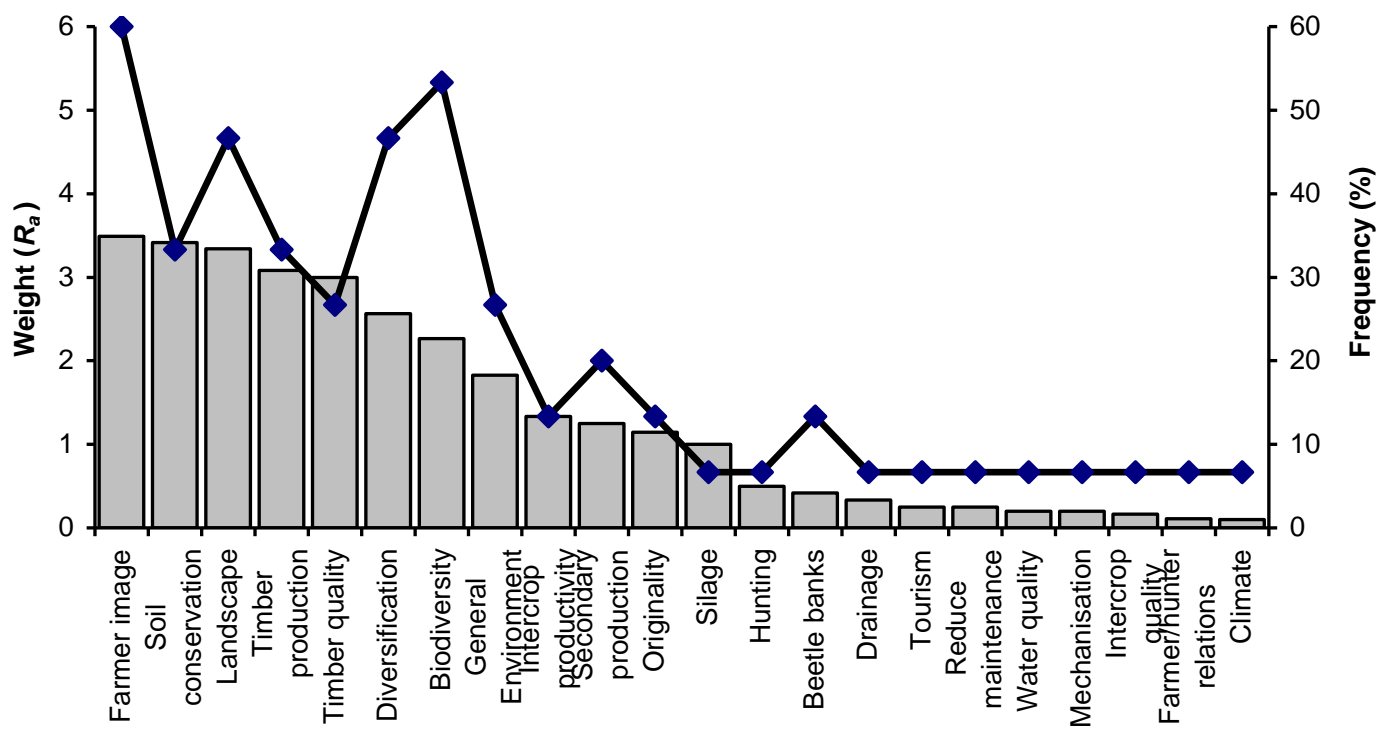

b) Negative perceptions

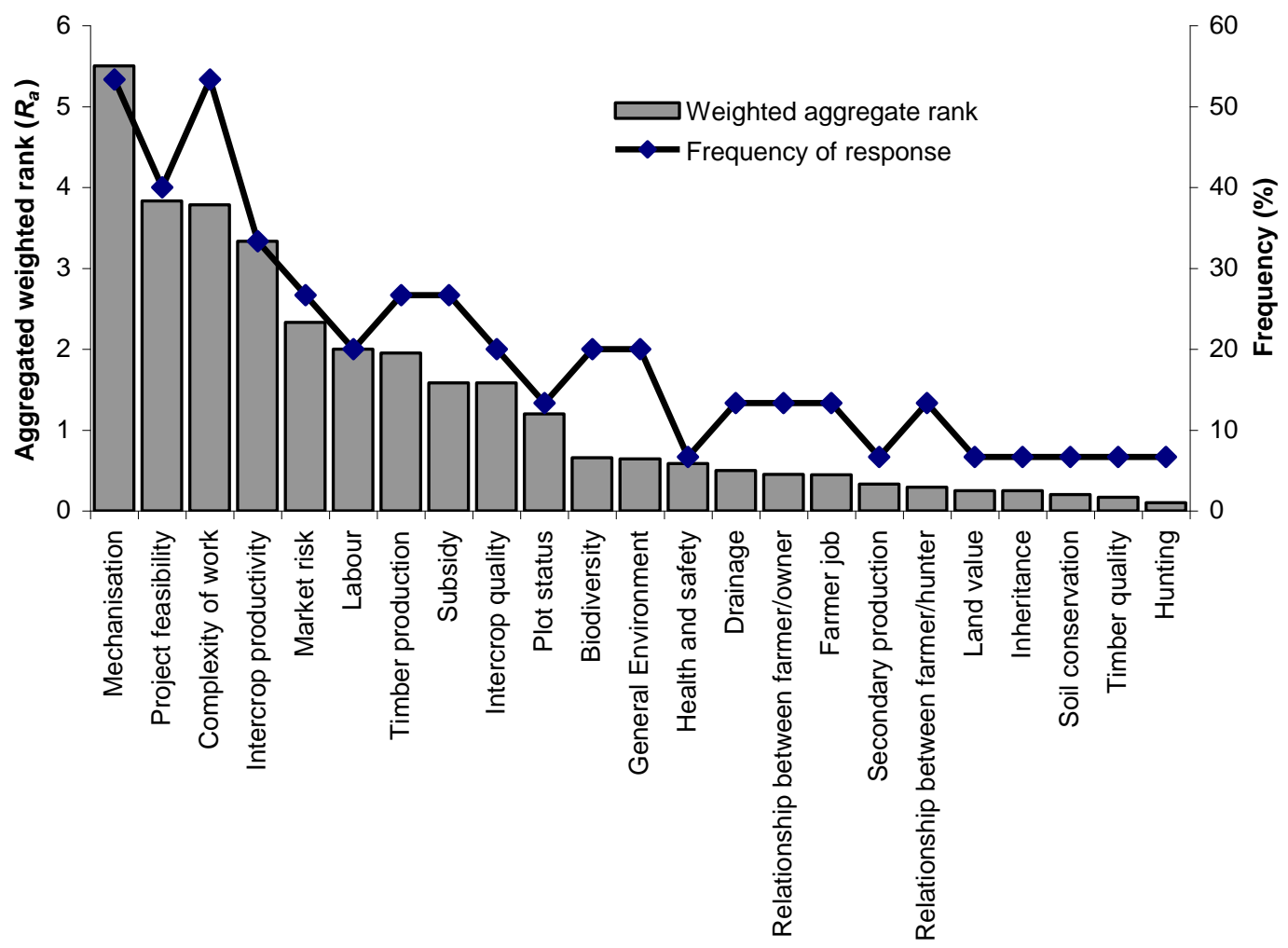


468 469
Figure 3 The weighted aggregate rank $\left(R_{a}\right)$ and frequency of response for perceived objectives of undertaking a silvoarable system given by the sample of 15 farmers in Bedfordshire.

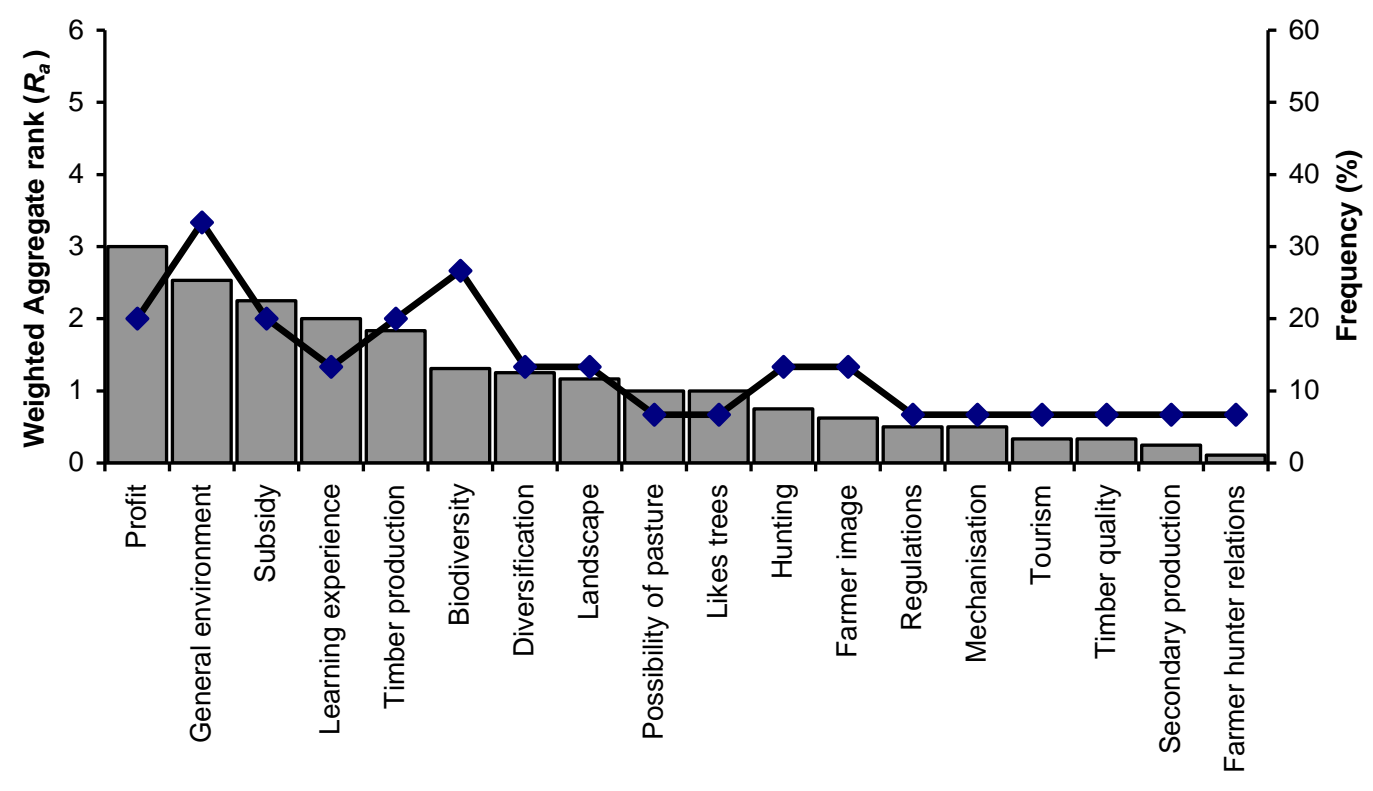

$\longrightarrow$ Frequency of response

Figure 4 Choice of a) crop and b) tree species that farmers would use.
a) Tree species
b) Crop species
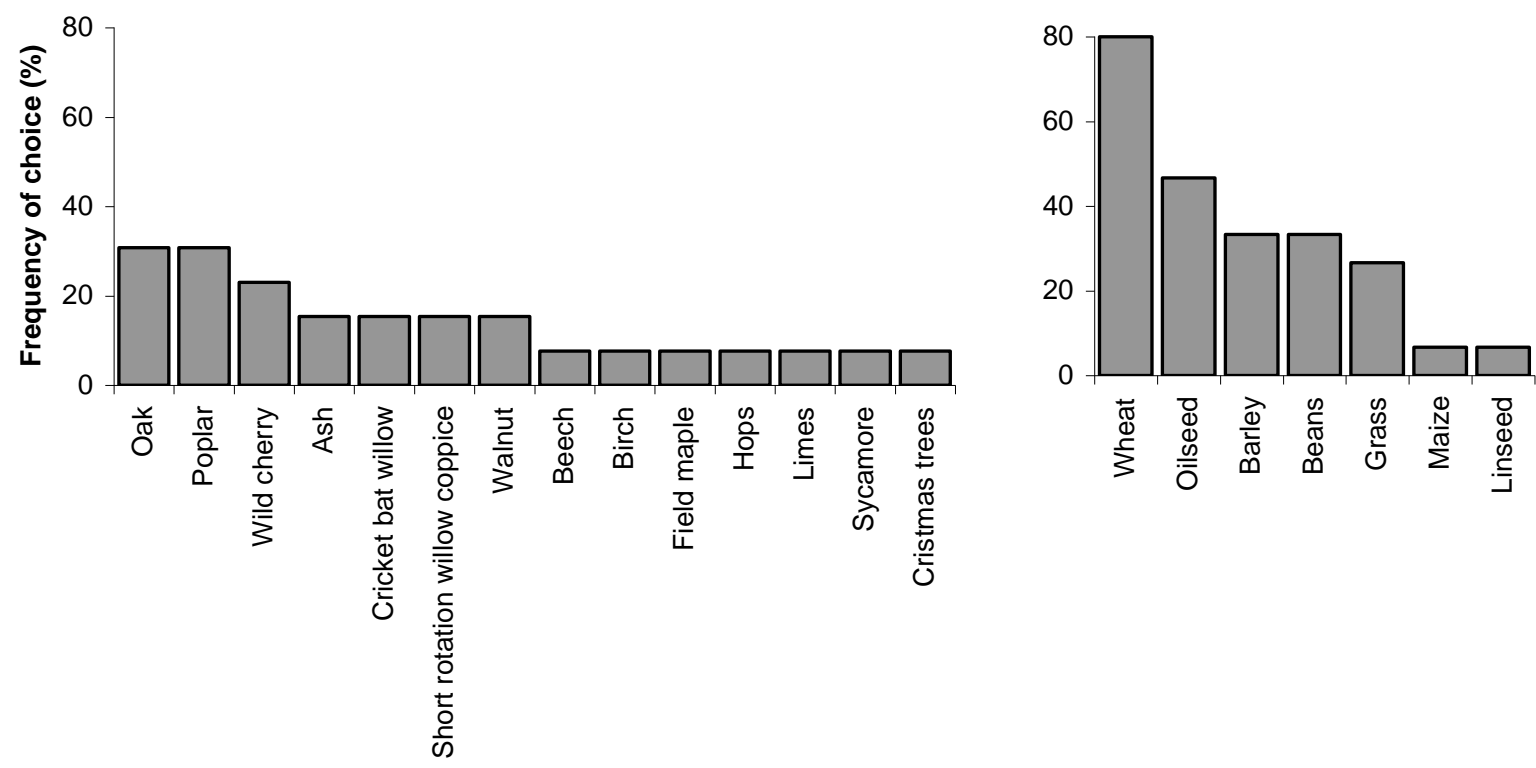